\title{
EGF Mediates Survival of Rat Cochlear Sensory Cells via an NF-kB Dependent Mechanism In Vitro
}

\author{
Yiqing Zheng ${ }^{1,2}$, Mark Rayner ${ }^{1}$, Ling Feng ${ }^{1}$, Xiaohua $\mathrm{Hu}^{1,3}$, Xin Zheng ${ }^{1}$, Ellalane Bearth ${ }^{1}$ and \\ Jizhen Lin*,
}

From the Departments of Otolaryngology ${ }^{l}$, University of Minnesota School of Medicine, Minneapolis, MN and the Department of Otolaryngology ${ }^{2}, 2^{\text {nd }}$ Affiliated Hospital of Sun-Yat-sen University ${ }^{2}$, Guangzhou, and Department of Otolaryngology ${ }^{3}$, Affiliated Union Hospital of Fujian Medical University, Fuzhou, China

\begin{abstract}
The survival of cochlear epithelial cells is of considerable importance, biologically. However, little is known about the growth factor(s) that are involved in the survival of cochlear sensory epithelial cells. In this study, we demonstrated that epidermal growth factor (EGF) plays a role in the survival of cochlear epithelial cells. Firstly, the presence of the EGF signaling pathway was demonstrated in the developing cochlear tissues of rats and a sensory epithelial cell line (OC1): -- epidermal growth factor receptor (EGFR), mitogen-activated protein kinase kinase (MAPKK), I kappa B alpha $(\mathrm{I} \kappa \mathrm{B} \alpha)$, nuclear factor kappa B (NF-אB), and B cell lymphoma 2 (Bcl-2). Secondly, the addition of EGF to OC1 increased the promoter activity of NF-KB and cell viability but not cell cycle progression and cell number increase -- which suggests that EGF is for cellular survival rather than cell proliferation of OC1. Finally, pyrrolidine dithiocarbamate (PDTC, an in-

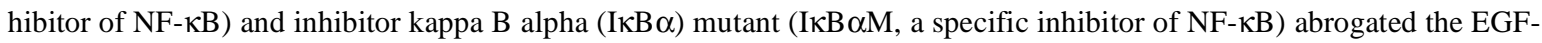
induced NF- $\mathrm{KB}$ activity and cell survival. These data suggest that EGF plays a role in the survival of cochlear sensory epithelial cells through the EGFR/MAPKK/I $\mathrm{BB} \alpha / \mathrm{NF}-\kappa \mathrm{B} / \mathrm{Bcl}-2$ pathway.
\end{abstract}

Keywords: Epidermal growth factor, signal molecules, cell survival, sensory epithelial cells, cochlear development, rat.

\section{INTRODUCTION}

The survival of sensory epithelial cells in the cochlear tissue is an important issue in the clinical settings when they are endangered during the disease process such as sudden senosrineural hearing loss. However, little is known about the growth factors that are involved in the cellular survival of cochlear sensory epithelial cells. As a result, there is no effective remedy for protecting cells from death during the disease process of sudden sensorineural hearing loss. Therefore, there is an urgent need for identification of growth factors that can preserve sensory epithelial cells when they are under the stressful conditions such as viral infection, aminoglycoside antibiotic use, noise exposure, etc.

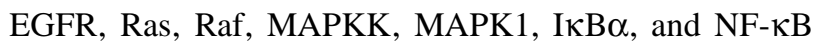
are important signaling molecules in the MAPK pathway and respond to extracellular mitogenic stimuli. Bcl-2 is a downstream molecule of NF- $\mathrm{\kappa B}$ and is involved in cellular survival [1]. Therefore, the EGF/NF- $\kappa \mathrm{B} / \mathrm{Bcl}-2$ signaling pathway may be involved in the cellular survival of sensory epithelial cells in the organ of Corti. EGF is a mitogen for cochlear stem cells [2], but may not be so for non-cochlear stem cells such as progenitor hair cells and sensory epithelial cells at the late stage of cochlear development. It is widely accepted that cochlear sensory epithelial cells proliferate within a short period of time and cease to proliferate thereafter $[3,4]$. The EGFR signaling pathway may have different

*Address correspondence to this author at the $20016^{\text {th }}$ Street SE, Room 216 Lions Research Bldg, Minneapolis MN 55455, USA; Tel: (612) 626-9872; Fax: (612) 626-9871; E-mail: linxx004@umn.edu roles in the cochlear stem cells and committed cochlear sensory epithelial cells.

EGF, an essential growth factor for epithelial cells, stimulates the proliferation of otospheres [5,6]. It is involved in the production of supernumerary hair cells in the rat neonatal organ of Corti [7] and is required for in vitro growth and differentiation of cochlear sensory hair cells [8]. EGFR is expressed in the otospheres [6], in the postnatal cochlear tissues of rodents $[9,10]$, and in the human fetal inner ear [11]. EGFR has a family comprising of four homologous receptors, e.g., EGFR (HER1/ErbB1), ErbB2/neu (HER2), ErbB3 (HER3) and ErbB4 (HER4) [12,13]. Thus, the knockout of ErbB4 alone [14] may not affect the cochlear development in mice because of their redundancies. It is well accepted that EGFR ligands activate the receptor tyrosine kinase in a tissue-specific manner. There are a variety of ways for EGFR to activate the receptor tyrosine kinase, as exemplified in Drosphila [15].

We hypothesized in this study that the EGF signaling pathway is involved in the survival of cochlear sensory epithelial cells from the postnatal day 5 organ of Corti which are relatively developed. First, a dynamic expression of the EGF-related signal molecules in the embryonic and postnatal cochlear tissues was investigated in vivo. Second, EGF was used to stimulate $\mathrm{OC} 1$ in order to evaluate its effects on cellular survival using cellular and molecular biological techniques. The results indicated that the EGFR, Ras, Raf, MAPKK, I $\kappa \mathrm{B} \alpha, \mathrm{NF}-\kappa \mathrm{B}$ and Bcl-2 molecules were expressed in the rat embryonic and postnatal cochlear tissues. The in vitro studies demonstrated that EGF increases the viability and survival of cochlear sensory epithelial cells, instead of 
cellular proliferation as shown in the cochlear stem cells of mice [2].

\section{MATERIALS AND METHODS}

\section{Materials}

OC1 is a cochlear sensory epithelial cell line from a postnatal Day 5 rat organ of Corti [16]. The study was approved by the Institutional Animal Care and Use Committee (IACUC). The cell line was considered to be progenitor hair cells because they expressed (i) multiple hair cell markers Brn3.1 (POU4f3), myosin VIIa, $\alpha 9$ Ach receptor, oncomodulin, calretinin, Id1, Id3, and (ii) early neural cell marker nestin [17] that is positive for most cells in the neuroepithelium before neurogenesis [18]. None of these hair cell markers are specific to cochlear hair cells but their expression in combination is restricted to cochlear hair cells.

Pyrrolidine dithiocarbamate (PDTC), an inhibitor which suppresses proteasome-mediated protein degradation, was used as an inhibitor of the NF- $\kappa \mathrm{B}$ activity by preventing $\mathrm{I} \kappa \mathrm{B} \alpha$ degradation. PDTC was chosen because it had been widely used as an inhibitor of NF- $\kappa \mathrm{B}$, especially in neurons [19] and cochlear sensory epithelial cells [20]. The NF- $\kappa B$ reporter, provided by Dr. Keith Brown at the National Institute of Allergy and Infectious Diseases, contains three repeats of $\kappa B$ sites for the immunoglobulin $\kappa$-light chain [21]. pCMV- $\beta$-galactosidase $(\beta$-gal) reporter plasmids were purchased from Stratagene. The $\beta$-gal activity is used as an internal control for NF- $\kappa \mathrm{B}$ luciferase activity in this study. Camptothecin was used as a unversal inducer of apoptosis for all cells [22].

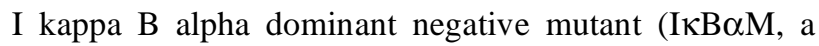
kind gift of Dr. Inder Verma at Salk Institute, La Jolla, CA), for which serine at position 36 had been changed to alanine, thus preventing phosphorylation and subsequent proteosomal degradation in response to stimuli $[23,24]$, is a specific inhibitor of NF- $\mathrm{B}$ activity. NF- $\kappa \mathrm{B}$ subunit p65 (a kind gift of Dr. Frank Ondrey at the Cancer Center, University of Minnesota, MN) is a cDNA construct for strengthening NF- $\mathrm{KB}$ activity in $\mathrm{OC} 1$ cells.

\section{Cell Culture Media}

OC1 cells were maintained in MEM media (Sigma) supplemented with $20 \mathrm{mM}$ Hepes, $2 \mathrm{mM}$ L-glutamine, $10 \mathrm{~mL} / \mathrm{L}$ nonessential amino acid, $0.4 \mu \mathrm{g} / \mathrm{mL}$ hydrocortisone, 5 $\mu \mathrm{g} / \mathrm{mL}$ insulin, $2.5 \mu \mathrm{g} / \mathrm{mL}$ transferrin, $20 \mathrm{ng} / \mathrm{mL}$ EGF (R\&D Systems), $10 \%$ fetal bovine serum (FBS, ATCC), $50 \mu \mathrm{g} / \mathrm{mL}$ streptomycin, and 50 units $/ \mathrm{mL}$ penicillin (hereafter referred to as growth media). In the growth media, EGF was omitted and fetal bovine serum (FBS) was reduced to $4 \%$ (thereafter referred to as basic media) 48 hours before experimenting. For OC1 transfection, Opti-MEM supplemented with 6 $\mu \mathrm{g} / \mathrm{mL}$ polybrene ${ }^{\circledR}$ (Invitrogen, thereafter referred to as transfection media) was used in this study.

\section{Affymetrix Microarrays}

The cochlear tissues on embryonic and postnatal days (E12, E14, E16, E18, and P1) were routinely dissected and Affymetrix microarrays were performed on these tissues, as previously decribed [25]. Briefly, approximately 15-20 pieces of embryonic and postnatal mouse cochlear tissues at each time point were dissected and pooled for RNA isola- tion, using the StrataPrep $^{\mathrm{R}}$ Total RNA Miniprep Kit (Stratagene), and approximately 30-50 $\mu \mathrm{g}$ of RNA were isolated from each time point. A total of $20 \mu \mathrm{g}$ RNA were used for each microarray analysis. cDNAs were prepared from the above RNA sample using the double-strand DNA synthesis kit (Life Technologies, Rockville, MD). cRNAs were synthesized from cDNAs and biotinylated using the BioArray High Yield RNA Transcript Labeling Kit (Enzo Diagnostics, Farmingdale, NY). Fifteen $\mu \mathrm{g}$ of fragmented cRNAs were hybridized to the Rat U34 chip (Affymetrix). Signals were detected with anti-streptavidin antibody, scanned into a computer, and normalized with a set of house-keeping genes within the Rat U34 chips. Three sets of the chips at each point in time were run in this study using 3 batches of RNA samples with each RNA sample from 15-20 embryonic and postnatal mouse cochlear tissues respectively. Relative mRNA expression levels are presented as relative light unit (RLU, mean $\pm \mathrm{SD}, \mathrm{n}=3$ ). The data presented in this study represent signal molecules related to the EGFR signaling pathway. The microarray database, published previously $[20,25]$, was interrogated with respect to genes of interest in the present study.

\section{RT-PCR}

Total RNA was isolated from embryonic (E14) and postnatal (P1) cochlear tissues. The specific primers for the EGFR (5' -agtggtccttggaaacttgg-3'/5' -gttgacatccatctggtacg3'), n-ras (5'-gaaagagggaactgaaacgatt-3'/5' -taggctgaaaga gagggatggt-3'), c-raf (5'-gggaaatagaagccagtg aggt-3'/5' caattagctggaacatctggaa-3'), Bcl-2 (5'- gacctctgtttgattctcc-3'/ 5'-tggtccatccttgataatgc-3') were designed with Oligo 4.0, and the specificity of the primers was confirmed by the BLAST search engine provided by the National Center of Biologic Information website (fttp://www.ncbi.nlm.nih.gov). RT-PCR was performed as described previously [16] using ribosomal protein S29 as a loading control. PCR products, routinely sequenced, were analyzed on a $2 \%$ agarose gel.

\section{Apoptotic Analysis}

Yopro-1 permits cytofluorometric analysis of programmed cell death [26]. Cells were cultured in 8-well chamber slides. Cells (approximately 20,000 cells) were plated onto 8 -well chamber slides for 2 days in growth media (up to $30-40 \%$ confluence) that later changed to the basic media with and without the addition of EGF at $80 \mathrm{ng} / \mathrm{mL}$ for 17 hours. Cells were then challenged with camptothecin at $0.01 \mu \mathrm{g} / \mathrm{mL}$ for 2 hours; the cells were then stained with Yopro- 1 reagents according to the manufacturer's instructions and were followed by DAPI staining. The total cells (DAPI positive), necrotic cells (red), and apoptotic cells (green) were counted in 5 high power fields (HPF). The percent of apoptotic and necrotic cells over the total amount of cells was calculated. Experiments were run in triplicates. Data are presented as mean $\pm \mathrm{SD}, \mathrm{n}=3$.

\section{Western Blot}

Cells were cultured in $\mathrm{T}_{25}$-flasks with growth media till $60 \%$ confluence, harvested for cytosolic and nuclear protein isolation. Protein samples were electrophoresed and blotted onto a nylon membrane, incubated with specific $\operatorname{I\kappa B} \alpha(1$ : 2000 , Cell Signaling) primary antibody and then a secondary antibody. The specific protein band for I $\mathrm{KB} \alpha$ was detected 
by using ECL Western blotting detection reagents and analysis system (Amersham Biosciences Piscataway, NJ) according to the manufacturer's instructions. In a similar way, NFKB subunit p65 and glyceraldehyde-3-phosphate-dehydrogenase (GAPDH) protein bands were detected using p65 (1:1000, Novus Biologicals) and GAPDH (1:2000, Novus Biologicals) specific antibodies. Western blot was repeated twice and representative data is shown.

\section{${ }^{3} \mathrm{H}$-Thymidine Incorporation}

Cells were cultured in 96-well plates with growth media till $40 \%$ confluence starved for 24 hours, incubated with EGF at $80 \mathrm{ng} / \mathrm{mL}$ or transfected with Id1 (a positive control for cell proliferation) and $1 \mu \mathrm{Ci}$ of ${ }^{3} \mathrm{H}$-thymidine in basic media for 6 hours, washed in phosphate-buffered saline (PBS) twice, and digested in a $0.25 \mathrm{~N}$ sodium hydroxide and $0.25 \%$ sodium dodecyl sulfate (SDS) solution at $37^{\circ} \mathrm{C}$ for 1 hour. The cells were then transferred to $1 \mathrm{~mL}$ of scintillation fluid (Ecoscent A, National Diagnostics), mixed thoroughly, and digested for 2 hours prior to counting in a scintillation counter (Beckman). Cells transfected with Id1 served as positive controls. Cells from a duplicated plate of the above experiment were counted by Trypan blue exclusion. The results are presented as counts per minute (CPM) over $10^{4}$ cells. Similarly, BrdU incorporation was performed by incubation of cells with BrdU instead of ${ }^{3} \mathrm{H}$-thymidine. For Trypan blue exclusion, cells were dissociated with trypsinEDTA, washed with PBS, stained with Trypan blue, counted with a hemacytometer. Both viable and dead cells were counted and viable cells were used for calculation of CPM per $10^{4}$ cells in ${ }^{3} \mathrm{H}$-thymidine experiments. The experiment was performed in triplicate.

\section{Flow Cytometry}

For cell cycle analysis, cells were cultured in 6-well plates till 60\% confluence, starved in growth media (omitting serum and EGF) for 24 hours, treated with and without EGF at $80 \mathrm{ng} / \mathrm{mL}$, washed with PBS, dissociated with trypsin-EDTA, washed with ice cold PBS, fixed with $100 \%$ ethanol, and stored at $-20^{\circ} \mathrm{C}$ until analysis. Approximately 3$5 \times 10^{4}$ cells were resuspended in $100 \mu \mathrm{L}$ of $40 \mu \mathrm{g} / \mathrm{mL}$ DNase-free RNase A with $100 \mu \mathrm{L}$ of $200 \mu \mathrm{g} / \mathrm{mL}$ propidium iodide added and was incubated for 30 minutes at room temperature. The fluorescence excited by FL-2 was measured on a FACScalibou (BD Biosciences). A total of $10^{4}$ cells per sample were analyzed. The cell cycle of OC1 cells was analyzed on CellQuest Pro software version 4.0 (Becton Dickinson, NJ). The experiment was run in triplicate. Data are presented as means $\pm \mathrm{SD}, \mathrm{n}=3$.

For apoptosis analysis, cells were cultured in $\mathrm{T}_{25}$-flasks till $60 \%$ confluence, starved in growth media (omitting serum and EGF) for 24 hours, treated with and without EGF at $80 \mathrm{ng} / \mathrm{mL}$, treated with and without EGF at $80 \mathrm{ng} / \mathrm{mL}$ or EGF+PDTC at 2.5 50 $\mu \mathrm{M}$ for 6 hours, washed with PBS, dissociated with trypsin-EDTA, washed with ice cold PBS. $300 \mu \mathrm{L}$ of 1.33x Annexin buffer was added to cells, followed by addition of $2 \mu \mathrm{L}$ Annexin-V-APC (BD Biosciences) to cells for 10 minutes at room temperature and finally by addition of 7-amino-actinomycin $\mathrm{D}$ (7-AAD, Invitrogen) to a final concentration of $50 \mathrm{ng} / \mathrm{mL}$ for additional 5 minutes prior to analysis. Annexin V staining identifies early apoptotic cells and 7-AAD staining indicates late apop- totic/necrotic cells. Viable cells are presented as \% of total cells (both Annexin-V/7-AAD positive and negative cells) using CellQuest Pro analysis software (version 4.0).

\section{Luciferase Assays}

Cells were cultured in 6-well plates till 60\% confluence, transfected with $1.4 \mu \mathrm{g} / \mathrm{mL}$ cDNAs (p65, IкB $\alpha \mathrm{M}$, or empty vector), co-transfected with reporters (NF- $\kappa \mathrm{B}$ and $\beta$-gal) in transfection media for 16 hours, and then incubated in growth media for 24 hours. Next, the cells were challenged with EGF at $80 \mathrm{ng} / \mathrm{mL}$ for 6 hours in the presence and absence of PDTC $(2.5 \mu \mathrm{M})$ and harvested for luciferase assays, as previously described [27]. The activity of luciferase reporter against $\beta$-gal (an internal control) is presented by a ratio of NF- $\kappa B$ luciferase over $\beta$-gal reporter (relative luciferase activity, RLA). The experiment was performed in triplicate.

\section{Statistical Analysis}

The student's $t$-test for unequal variances was used in the above experiments. $P$ values less than 0.05 was considered
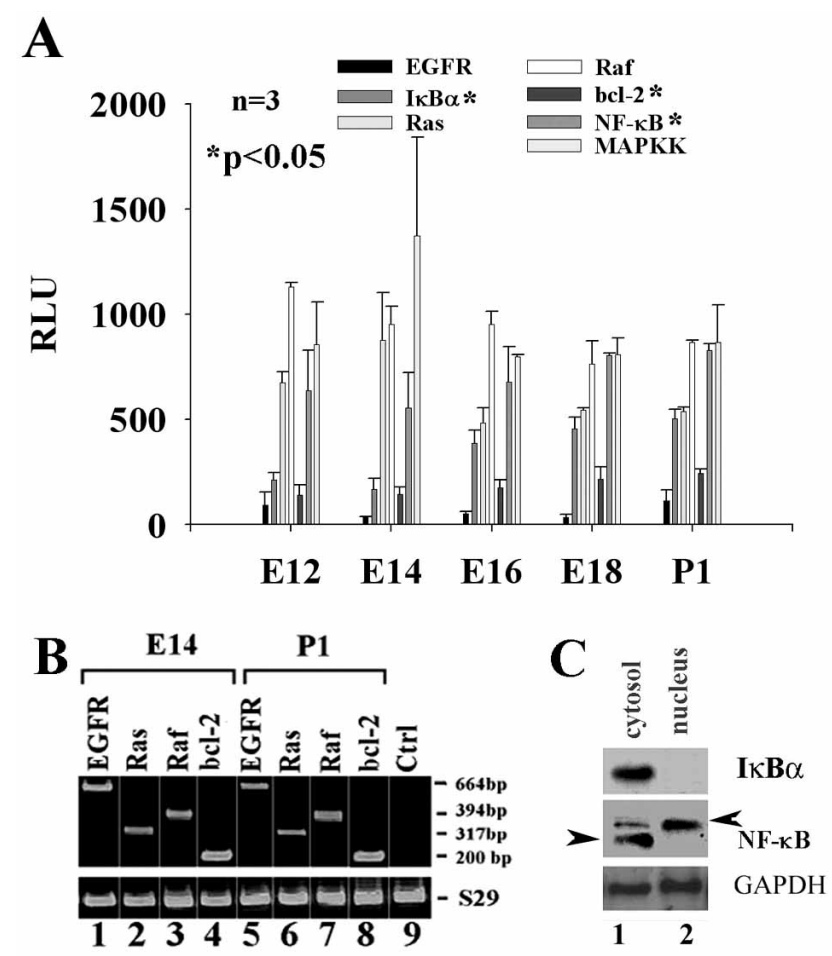

Fig. (1). Existence of the EGF signaling pathway in the developing cochlear tissues. A, microarray data: EGFR, Raf, Ras, MAPKK, $\mathrm{I} \kappa \mathrm{B} \alpha, \mathrm{NF}-\kappa \mathrm{B}$ (p105, the precursor for both p65 and p50 subunits), and Bcl-2 were dynamically expressed in the developing cochlear tissue from E12 to P1. B, the expression of the EGFR, ras, raf, and $\mathrm{Bcl}-2$ genes on the E14 and P1 tissues was confirmed by RT-PCR. $\mathrm{C}$, the expression of $\mathrm{I} \kappa \mathrm{B} \alpha$ and $\mathrm{NF}-\kappa \mathrm{B}$ was verified in the developing cochlear tissues on E14 by Western blot in which NF- $\kappa \mathrm{B}$ (p65 subunit) was partially translocated into the nucleus (arrowhead, lane 2, active p65) and partially in the cytosol (lane 1, inactive p65). GM, growth media; Ctrl, PCR negative control with omitting mRNA sample; S29, ribosomal protein S29; GAPDH, glyseraldehyde-3-phosphate dehydrogenase. ${ }^{*} \mathrm{p}<0.05$, comparison was made among E12, E14, E16, E18, and P1 by ANOVA. 
significant. Analysis of variance (ANOVA) was used for evaluation of the difference between multiple experiments.

\section{RESULTS}

Multiple Molecules in the EGF Signaling Pathway are Expressed in the Developing Cochlea of Rats

Microarray data demonstrated the expression of the EGFR, Ras, Raf, MAPKK, I $\kappa \mathrm{B} \alpha$, NF- $\kappa \mathrm{B}$, and Bcl-2 mRNA transcripts in the developing cochlear tissue of rats from E12 to P1. Dynamic expression patterns of these genes are presented in Fig. (1A). To verify the positive results of the microarray data, cochlear tissues on E14 and P1, OC1 cells were used for examination of the above gene expression. EGFR, Raf, Ras, MAPKK, I $\kappa \mathrm{B} \alpha, \mathrm{NF}-\kappa \mathrm{B}$ and $\mathrm{Bcl}-2$ were expressed in the E14 and P1 cochlear tissues as determined by RT-PCR or Western blot. The data are presented in Fig. (1B and 1C), respectively. Unlike $\mathrm{I} \kappa \mathrm{B} \alpha, \mathrm{NF}-\kappa \mathrm{B}$ subunit p65 was found in the both cytosol and the nucleus by Western blot, which indicates the partial translocation of $\mathrm{NF}-\kappa \mathrm{B}$ subunit p65, e.g., activation of NF- $\mathrm{\kappa B}$.

\section{EGF has Significant Effects on the Resistance of OC1 to Camptothecin Induced Cell Death}

EGF has been shown to stimulate the proliferation of embryonic stem cells [28] and embryonic cochlear progenitor cells [8]. The incubation of OC1 cells with EGF at 80 $\mathrm{ng} / \mathrm{mL}$ for 6 hours did not significantly increase the incorporation of ${ }^{3} \mathrm{H}$-thymidine (Fig. (2A)) and cell cycle progression (from S-phase to G2/M-phase) compared with the controls-although some Go/G1 to S-phase progression was observed (Fig. (2B), S-phase cells $=24.3 \pm 2.3 \%$ in EGF-treated cells and $21.8 \pm 1.8 \%$ in control cells), which indicated little to no cell proliferation induced by EGF. Incubation of OC1 cells with EGF at $80 \mathrm{ng} / \mathrm{mL}$ for 24 hours did not show a significant change of cell numbers (Fig. (2C)). However, the incubation of OC1 cells with EGF at $80 \mathrm{ng} / \mathrm{mL}$ for 3 days increased cell numbers compared with the controls (Fig. (2D)). It suggests that an increase of cell numbers is not due to active cell proliferation but increased cell survival. Consistent with this, cells challenged with camptothecin at $0.01 \mathrm{mg} / \mathrm{mL}$ underwent apoptosis $(86.7 \pm 6.8 \%, n=3)$ and necrosis $(97.3 \pm 7.9 \%, \mathrm{n}=3)$ without EGF whereas only $14.3 \pm 3.1 \%$ underwent necrosis and $23.4 \pm 5.3 \%$ underwent apoptosis with EGF Fig. (2E, representative data). Taken all together, these data indicates that EGF increases the survival of $\mathrm{OC} 1$. Unlike EGF, Id1 (a positive control for cellular growth and proliferation) has significant effects on both DNA synthesis and cell numbers.

\section{EGF Increases the Promoter Activity of NF- $\mathrm{KB}$ in $\mathrm{OC1}$ Cells}

$\mathrm{NF}-\kappa \mathrm{B}$ is involved in the cellular activation in many cells. To study whether or not EGF increases the promoter activity of $\mathrm{NF}-\kappa \mathrm{B}$, luciferase assays were performed. Cells were incubated with EGF at $80 \mathrm{ng} / \mathrm{mL}$ for 6 hours, significantly increasing the promoter activity of $\mathrm{NF}-\kappa \mathrm{B}$ in $\mathrm{OC} 1$ compared with the controls. Whereas PDTC, an inhibitor for $N F-\kappa B$, significantly down regulated the promoter activity of $\mathrm{NF}-\kappa \mathrm{B}$ induced by EGF (Fig. (3A)). NF- $\kappa \mathrm{B}$ is involved in cellular resistance to aminoglycoside cytotoxicity [29]. To compare the potency of EGF with p65 (a subunit of the NF$\kappa \mathrm{B}$ heterodimers), OC1 cells were incubated with EGF and transfected with the NF- $\kappa \mathrm{B}$ reporter. EGF significantly in-

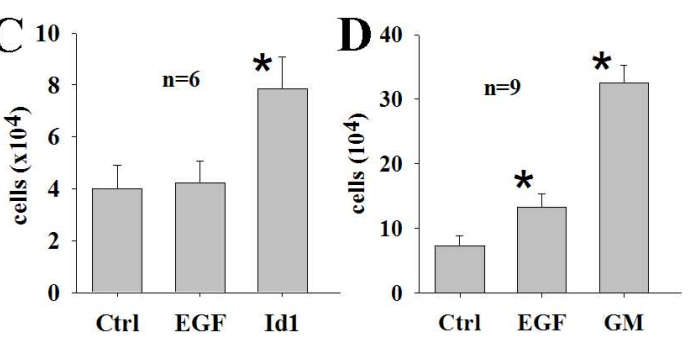

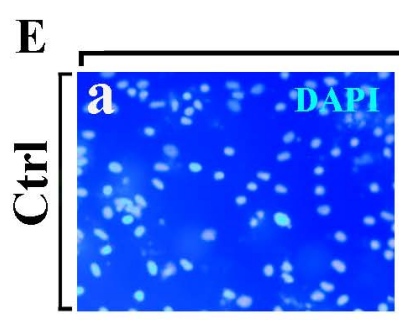

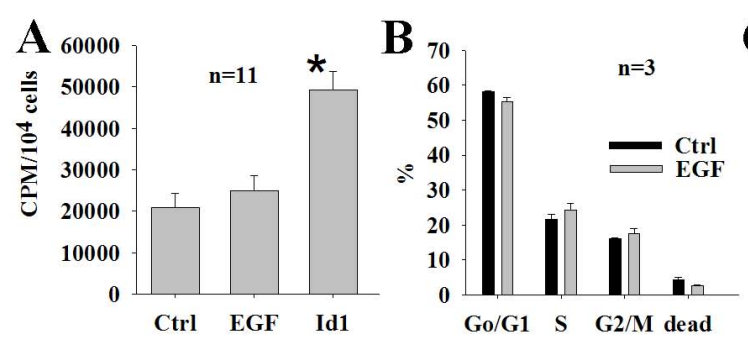

camptothecin $0.01 \mathrm{mg} / \mathrm{mL}$ for 2 hours
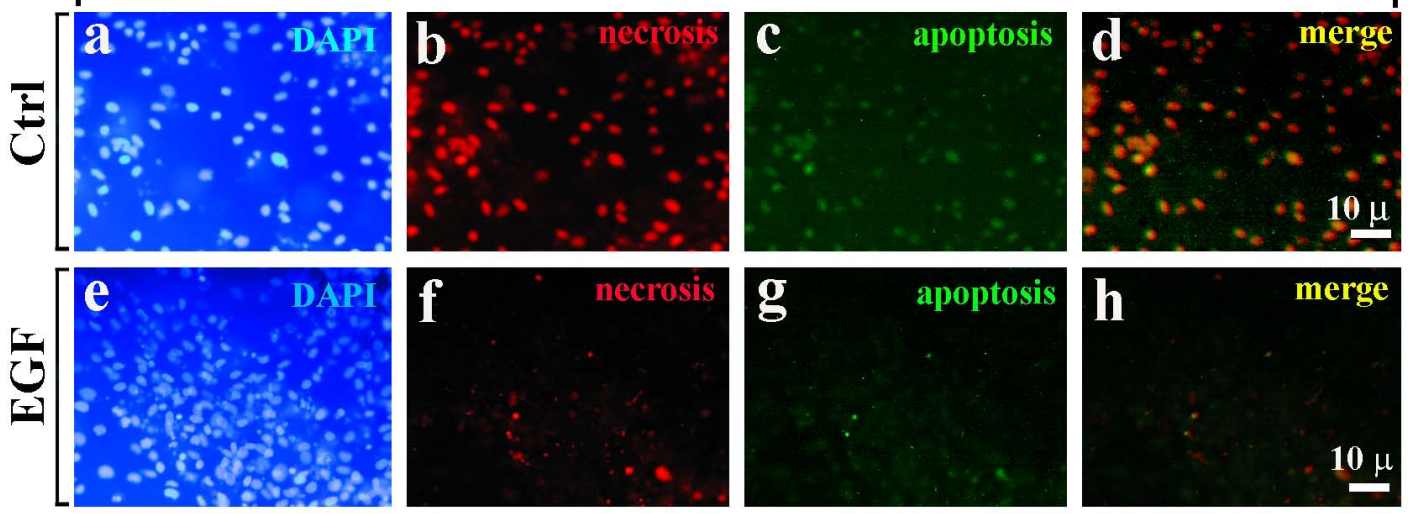

Fig. (2). Commitment of EGF to cellular survival but not cell proliferation of OC1. In 6-hour incubation, EGF had no significant effects on the ${ }^{3} \mathrm{H}$-thymidine incorporation in OC1 cells compared with controls (A). Similarly, EGF had no effect on cell cycle progression from Go/G1-phase to S-phase within 6 hours compared with controls (B) and cell numbers (C). However, in 3-day cultures, EGF had more cell counts than control (D), due to an increase of cell survival. EGF significantly reduced cellular apoptosis and necrosis induced by camptothecin $(\mathbf{E})$. Id1 served as a positive control for DNA synthesis $(\mathbf{A})$ and cell counting $(\mathbf{C})$. bar=10 $\mu$ m applying to a-I; n=total samples from 3 separated experiments. 
creased the promoter activity of NF- $\mathrm{\kappa B}$ although not as high as p65 (Fig. (3B)). To study whether EGF-increased NF- $\mathrm{KB}$ promoter activity via IKB $\alpha, \mathrm{OC} 1$ cells were incubated with EGF in the presence and absence of a specific I $\mathrm{I} B \alpha$ inhibitor (I $\mathrm{B} \alpha \mathrm{M})$ which is able to capture p50 and p65 but is resistant to phosphorylation by IкB kinases and thus prevents the activiation of NF- $\kappa B$. The results indicated that I $\kappa \mathrm{B} \alpha \mathrm{M}$ significantly inhibited the NF- $\mathrm{KB}$ promoter activity by EGF (Fig. (3B)), suggesting that EGF-induced NF- $\kappa B$ activity is via the classic NF- $\mathrm{KB}$ pathway, namely, EGFR $\rightarrow$ Ras $\rightarrow$ $\mathrm{Raf} \rightarrow \mathrm{Erk} \rightarrow \mathrm{I} \kappa \mathrm{B} \alpha \rightarrow \mathrm{NF}-\kappa \mathrm{B}$. To study whether EGF affects cellular viability, flow cytometry was performed. Incubation of OC1 cells with EGF at $80 \mathrm{ng} / \mathrm{mL}$ significantly increased cell viability $(95.4 \% \pm 3.5 \%)$ (Fig. (3C)) in comparison with the control $(85.4 \% \pm 3.2 \%$, Fig. (3C)). PDTC at $2.5 \mu \mathrm{M}$ abrogated the action induced by EGF (68.1\% $\pm 2.7 \%$ ) (Fig. (3C)). PDTC at $50 \mu \mathrm{M}$ was apoptotic to $\mathrm{OC} 1$ in the presence of EGF (25.5\% $\pm 2.7 \%$ ) (Fig. (3C)).

Taken together, the data suggests that EGF has very little or no effect on cell proliferation of OC1 (Fig. (2)) but has significant effects on cell survival through the up-regulation of NF- $\kappa \mathrm{B}$ activity in OC1 cells (Fig. (3)). It is also noted that inhibition of NF- $\kappa B$ activity with PDTC or I $\mathrm{KB} \alpha \mathrm{M}$ reduces the cellular viability.

\section{DISCUSSION}

The survival of cells involves many pathways (MAPK/NF- $\mathrm{BB}, \mathrm{p} 38 \mathrm{MAPK} / \mathrm{NF}-\kappa \mathrm{B}, \mathrm{PI} 3 \mathrm{~K} / \mathrm{Akt} / \mathrm{AP} 1$, JNK/cjun, etc.) and it is dependent upon cell types and factors administered. The survival of OC1 cells by EGF is partially dependent upon the EGFR/Ras/Raf/ MAPKK/IкBa/NF$\kappa \mathrm{B} / \mathrm{Bcl}-2$ pathway in this study. First, the genes for the MAPK/NF- $\kappa B$ pathway are expressed in the embryonic and postnatal cochlear tissues. Second, EGF increases the survival of cultured sensory epithelial cells and makes them resistant to apoptotic agents such as camptothecin. Indeed, in the cell culture system, EGF is essential for the survival of sensory epithelial cells. Without EGF, cultured OC1 cells do not grow but undergo apoptosis.

EGF has been shown to act as a mitogen to stimulate a variety of stem cell proliferation. The addition of EGF to otospheres from P0 rat organ of Corti [6], vestibular stem cells from mice [30], and embryonic stem cells from mice [28] results in cell proliferation. In this study, the addition of EGF to cultured OC1 cells did not significantly change ${ }^{3} \mathrm{H}-$ thymidine incorporation and cell cycle progression, indicating that EGF has little or no effects on cell proliferation of OC1 cells that are derived from the postnatal day 5 rat organ of Corti. Thus, it is logicial to state that EGF serves as a mitogen for cochlear stem cells but it serves as a survival factor for $\mathrm{OC} 1$ cells. In addition to the cellular survival, our recent studies indicate that EGF represents a driving force for hair cell marker expression in both cochlear stem cells $[2,31]$ and OC1 cells (data not shown).

How EGF maintains cellular viability and survival of cochlear sensory epithelial cells remains unclear. In this study, we demonstrated that the classic NF- $\kappa \mathrm{B}$ pathway, EGFR/Ras/Raf/ MAPKK/IкB $\alpha / \mathrm{NF}-\kappa \mathrm{B} / \mathrm{Bcl}-2$ pathway, exists in the cochlear tissue and cochlear sensory epithelial cells. Indeed, EGF significantly increases the promoter activ-

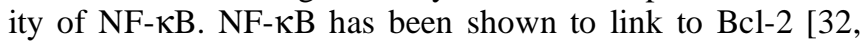
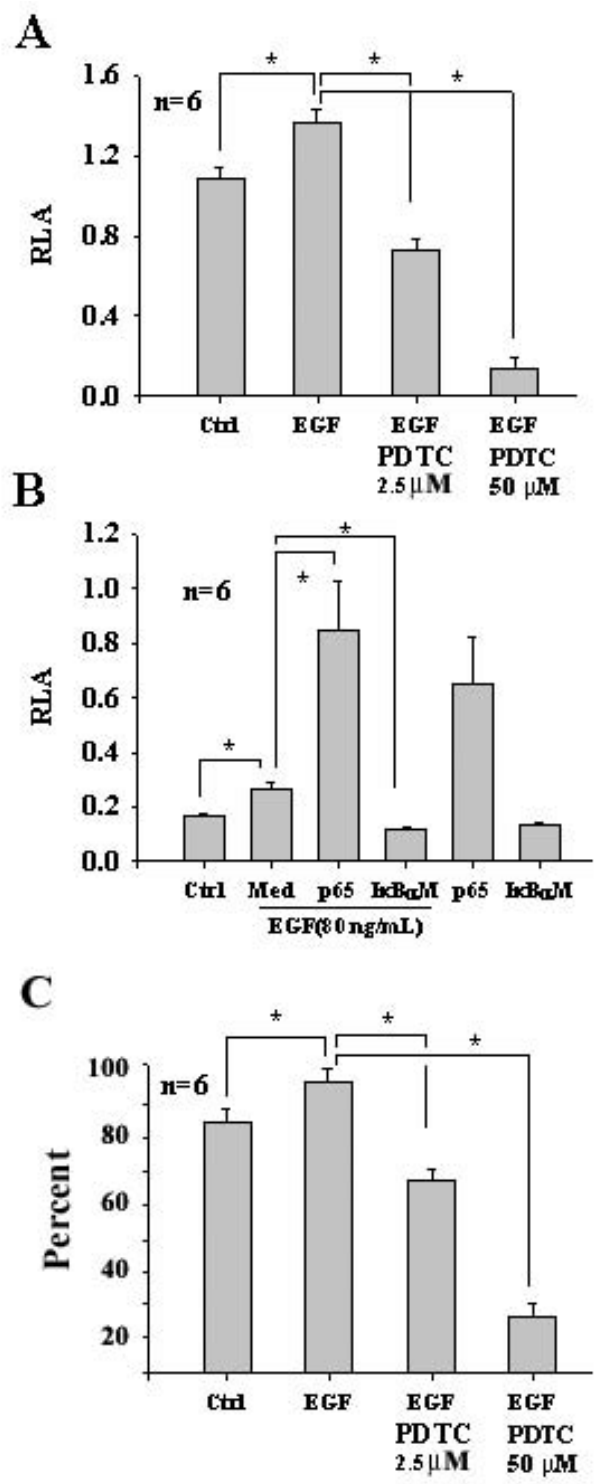

Fig. (3). Increase of the NF- $\kappa \mathrm{B}$ promoter activity and cell survival by EGF in OC1 cells. Incubation of OC1 cells with EGF at 80 $\mathrm{ng} / \mathrm{mL}$ significantly upregulated the NF- $\kappa \mathrm{B}$ promoter activity whereas PDTC at $2.5 \mu \mathrm{M}$ significantly reduced the NF- $\kappa \mathrm{B}$ promoter activity induced by EGF and PDTC at $50 \mu \mathrm{M}$ dramatically reduced the NF- $\kappa B$ promoter activity (A, due to cell apoptosis). EGF-induced NF- $\kappa \mathrm{B}$ promoter activity was significantly enhanced by $\mathrm{p} 65$ at $1.4 \mu \mathrm{g} / \mathrm{mL}$ but abrogated by $\mathrm{I} \kappa \mathrm{B} \alpha \mathrm{M}$ at $1.4 \mu \mathrm{g} / \mathrm{mL}$ in $\mathrm{OC} 1$ cells $(\mathbf{B})$. EGF and p65 additively regulated the NF- $\mathrm{KB}$ promoter activity in OC1 cells and p65 had a potent effect on the NF$\kappa \mathrm{B}$ promoter activity. Flow cytometry for Annexin-V and 7-AAD demonstrated that EGF had a significant effect on cell viability compared with control and the action was abrogated by PDTC $(\mathbf{C})$. It is noted that PDTC at $50 \mu \mathrm{M}$ was apoptotic to OC1 cells. ${ }^{*} \mathrm{p}<0.05$. Med, MEM media without supplements; Ctrl, control. It is also noted that relative luciferase activity (RLA) is different between data sets $\mathrm{A}$ and $\mathrm{B}$ due to transfection efficiency between these two independent experiments: $\beta$-gal in data set $A$ is less efficient than that in data set $B$. $n=$ total samples from 3 separated experiments.

33]. In the ear, the Bcl-2 family serves as the primary control over cell survival and death $[1,34]$. For cells to survive, a 
certain level of NF- $\kappa B$ activity is necessary because a full blockage of the NF- $\kappa B$ activity with PDTC at $50 \mu \mathrm{M}$ (a recommended dose for inhibition of NF- $\mathrm{KB}$ activity in other cell types such as keratinocytes) causes complete cell death of OC1 cells. However, PDTC is capable of inhibiting the activity of nitric oxide metabolism. We cannot exclude the possibility that cellular apoptosis by PDTC is in part due to the inhibition of nitric oxide metabolism. The fact that I $\kappa \mathrm{B} \alpha \mathrm{M}$ specifically inhibits the NF- $\kappa \mathrm{B}$ pathway, showing the similar results, suggests that the NF- $\mathrm{\kappa B}$ signaling pathway is in part responsible for EGF-induced cell survival.

Another issue that needs to be addressed is why Id1induced NF- $\kappa \mathrm{B}$ activity is linked to cellular proliferation via cyclin D1 [20] whereas EGF-induced NF- $\kappa B$ activity is linked to cell survival. In addition, other candidate growth factors and transcription factors are involved in survival include $N$-methyl-D-aspartate receptor antagonist (MK801) [35], neurotrophins (NT3, GDNF, and BDNF) [35-37], basic fibroblast growth factor (bFGF) [38-41], insulin-like growth factor-1 (IGF-1) [30,42], Id1 [25,43], Id3 [44], and plateletderived growth factor (PDGF) [25]. It is expected that multiple factors participate in cell survival of cochlear sensory epithelial cells. How these factors collaborate to make sensory epithelial cells survived for a life-time span is an important issue for the physiology of sensory epithelial cells and warrants further studies.

\section{ACKNOWLEDGEMENTS}

We would like to thank Dan Guire for his editorial assistance and proofreading in the preparation of this manuscript.

This study is in part supported by the National Institutes of Health (grant \# P30CD04660, R01DC008165, and R03CA107989) and the University of Minnesota Academic Health Center.

\section{REFERENCES}

[1] Cheng AG, Cunningham LL, Rubel EW. Mechanisms of hair cell death and protection. Curr Opin Otolaryngol Head Neck Surg 2005; 13: 343-8.

[2] Lin J, Feng L, Fukudome S, Hamajima Y, Huang T, Levine S. Cochlear stem cells/progenitors and degenerative hearing disorders. Curr Med Chem 2007; 14: 2937-43.

[3] Ruben RJ. Development of the inner ear of the mouse: a radioautographic study of terminal mitoses. Acta Otolaryngol 1967; 220: 144.

[4] Roberson DW, Rubel EW. Cell division in the gerbil cochlea after acoustic trauma. Am J Otol 1994; 15: 28-34.

[5] Malgrange B, Rogister B, Lefebvre PP, et al. Expression of growth factors and their receptors in the postnatal rat cochlea. Neurochem Res 1998; 23: 1133-8.

[6] Malgrange B, Belachew S, Thiry M, et al. Proliferative generation of mammalian auditory hair cells in culture. Mech Dev 2002; 112: 79-88.

[7] Lefebvre PP, Malgrange B, Thiry M, Van De Water TR, Moonen G. Epidermal growth factor upregulates production of supernumerary hair cells in neonatal rat organ of corti explants. Acta Otolaryngol 2000; 120: 142-5.

[8] Doetzlhofer A, White PM, Johnson JE, Segil N, Groves AK. In vitro growth and differentiation of mammalian sensory hair cell progenitors: a requirement for EGF and periotic mesenchyme. Dev Biol 2004; 272: 432-47.

[9] Zine A, Nyffeler M, de Ribaupierre F. Spatial expression patterns of epidermal growth factor receptor gene transcripts in the postnatal mammalian cochlea. Hear Res 2000; 141: 19-27.

[10] Hume CR, Kirkegaard M, Oesterle EC. ErbB expression: the mouse inner ear and maturation of the mitogenic response to heregulin. J Assoc Res Otolaryngol 2003; 4: 422-43.
[11] Yamashita H, Takahashi M, Bagger-Sjoback D. Expression of epidermal growth factor, epidermal growth factor receptor and transforming growth factor-alpha in the human fetal inner ear. Eur Arch Otorhinolaryngol 1996; 253: 494-7.

[12] Tidcombe H, Jackson-Fisher A, Mathers K, Stern DF, Gassmann $\mathrm{M}$, Golding JP. Neural and mammary gland defects in ErbB4 knockout mice genetically rescued from embryonic lethality. Proc Natl Acad Sci USA 2003; 100: 8281-6.

[13] Yarden Y, Sliwkowski MX. Untangling the ErbB signalling network. Nat Rev Mol Cell Biol 2001; 2: 127-37.

[14] Golding JP, Trainor P, Krumlauf R, Gassmann M. Defects in pathfinding by cranial neural crest cells in mice lacking the neuregulin receptor ErbB4. Nat Cell Biol 2000; 2: 103-9.

[15] Perrimon N, Perkins LA. There must be 50 ways to rule the signal: the case of the Drosophila EGF receptor. Cell 1997; 89: 13-6.

[16] Ozeki M, Duan L, Obritch W, Lin J. Establishment and characterization of progenitor hair cell lines in rats. Hear Res 2003; 179: 4352.

[17] Lendahl U, Zimmerman LB, McKay RD. CNS stem cells express a new class of intermediate filament protein. Cell 1990; 60: 585-95.

[18] Frederiksen K, McKay RD. Proliferation and differentiation of rat neuroepithelial precursor cells in vivo. J Neurosci 1988; 8: 114451 .

[19] Nurmi A, Vartiainen N, Pihlaja R, Goldsteins G, Yrjanheikki J, Koistinaho J. Pyrrolidine dithiocarbamate inhibits translocation of nuclear factor kappa-B in neurons and protects against brain ischaemia with a wide therapeutic time window. J Neurochem 2004; 91: 755-65.

[20] Ozeki M, Hamajima Y, Feng L, et al. Id1 induces the proliferation of cochlear sensorineural epithelial cells via the NF-kB/cyclin D1 pathway in vitro. J Neurosci Res 2007; 85: 515-24.

[21] Fujita T, Nolan GP, Liou HC, Scott ML, Baltimore D. The candidate proto-oncogene bcl-3 encodes a transcriptional coactivator that activates NF-kappa B p50 homodimers. Genes Dev 1993; 7: 135463 .

[22] Lansiaux A, Facompre M, Wattez N, et al. Apoptosis induced by the homocamptothecin anticancer drug BN80915 in HL-60 cells. Mol Pharmacol 2001; 60: 450-61.

[23] Van Antwerp DJ, Martin SJ, Kafri T, Green DR, Verma IM. Suppression of TNF-alpha-induced apoptosis by NF-kappaB. Science 1996; 274: 787-9.

[24] Gilmore TD, Koedood M, Piffat KA, White DW. Rel/NFkappaB/IkappaB proteins and cancer. Oncogene 1996; 13: 136778.

[25] Lee Y-W, Ozeki M, Juhn SK, Lin J. Expression of platelet-derived growth factor in the developing cochlea of rats. Acta Otolaryngol 2004; 124: 558-62.

[26] Idziorek T, Estaquier J, De Bels F, Ameisen JC. YOPRO-1 permits cytofluorometric analysis of programmed cell death (apoptosis) without interfering with cell viability. J Immunol Methods 1995; 185: 249-58

[27] Toyama K, Ozeki M, Hamajima Y, Lin J. Expression of the integrin genes in the developing cochlea of rats. Hear Res 2005; 201: 21-6.

[28] Li H, Roblin G, Liu H, Heller S. Generation of hair cells by stepwise differentiation of embryonic stem cells. Proc Natl Acad Sci USA 2003; 100: 13495-500.

[29] Jiang H, Sha SH, Schacht J. NF-kappaB pathway protects cochlear hair cells from aminoglycoside-induced ototoxicity. J Neurosci Res 2005; 79: 644-51.

[30] Li H, Liu H, Heller S. Pluripotent stem cells from the adult mouse inner ear. Nat Med 2003; 9: 1293-9.

[31] Lin J, Feng L, Hamajima Y, et al. Directed differentiation of mouse cochlear stem cells in vitro 2008; submitted.

[32] Chai J, Du C, Wu JW, Kyin S, Wang X, Shi Y. Structural and biochemical basis of apoptotic activation by Smac/DIABLO. Nature 2000; 406: 855-62.

[33] Verhagen AM, Ekert PG, Pakusch M, et al. Identification of DIABLO, a mammalian protein that promotes apoptosis by binding to and antagonizing IAP proteins. Cell 2000; 102: 43-53.

[34] Waters C. Molecular mechanisms of cell death in the ear. Ann N Y Acad Sci 1999; 884: 41-51.

[35] Duan M, Agerman K, Ernfors P, Canlon B. Complementary roles of neurotrophin 3 and a N-methyl-D-aspartate antagonist in the protection of noise and aminoglycoside-induced ototoxicity. Proc Natl Acad Sci USA 2000; 97: 7597-602. 
[36] Yagi M, Magal E, Sheng Z, Ang KA, Raphael Y. Hair cell protection from aminoglycoside ototoxicity by adenovirus-mediated overexpression of glial cell line-derived neurotrophic factor. Hum Gene Ther 1999; 10: 813-23.

[37] Feng L, Fukudome S, Wang D, Schlentz E, Lin J. BDNF increases the survival of rat sensory epithelial cells via the PI3K/AKT and NF-kB/BCL-2 signaling pathways submitted 2008.

[38] Maroon H, Walshe J, Mahmood R, Kiefer P, Dickson C, Mason I. Fgf3 and Fgf8 are required together for formation of the otic placode and vesicle. Development 2002; 129: 2099-108.

[39] Vendrell V, Carnicero E, Giraldez F, Alonso MT, Schimmang T. Induction of inner ear fate by FGF3. Development 2000; 127: 2011-9.

[40] Pirvola U, Spencer-Dene B, Xing-Qun L, et al. FGF/FGFR-2(IIIb) signaling is essential for inner ear morphogenesis. J Neurosci 2000; 20: 6125-34.
[41] Adamska M, Herbrand H, Adamski M, Kruger M, Braun T, Bober E. FGFs control the patterning of the inner ear but are not able to induce the full ear program. Mech Dev 2001; 109: 303-13.

[42] Li Y, Xiang J, Duan C. Insulin-like growth factor-binding protein-3 plays an important role in regulating pharyngeal skeleton and inner ear formation and differentiation. J Biol Chem 2005; 280: 3613-20.

[43] Lin J, Ozeki M, Javel E, et al. Identification of gene expression profiles in rat ears with cDNA microarrays. Hear Res 2003; 175: 2 13.

[44] Ozeki M, Schlentz EP, Lin J. Characterization of inhibitor of differentiation (Id3) gene expression in the developing cochlear tissue of rats. Acta Otolaryngol 2005; 125: 244-9.

(c) Zheng et al.; Licensee Bentham Open.

This is an open access article distributed under the terms of the Creative Commons Attribution License (http://creativecommons.org/licenses/by/2.5/), which permits unrestrictive use, distribution, and reproduction in any medium, provided the original work is properly cited. 